This item was submitted to Loughborough's Research Repository by the author.

Items in Figshare are protected by copyright, with all rights reserved, unless otherwise indicated.

\title{
Determinants of syndicated lending in European banks and the impact of the financial crisis
}

PLEASE CITE THE PUBLISHED VERSION

http://dx.doi.org/10.1016/j.intfin.2014.07.005

PUBLISHER

(c) Elsevier

VERSION

AM (Accepted Manuscript)

\section{PUBLISHER STATEMENT}

This work is made available according to the conditions of the Creative Commons Attribution-NonCommercialNoDerivatives 4.0 International (CC BY-NC-ND 4.0) licence. Full details of this licence are available at: https://creativecommons.org/licenses/by-nc-nd/4.0/

\section{LICENCE}

CC BY-NC-ND 4.0

\section{REPOSITORY RECORD}

Howcroft, Barry, Alper Kara, and David Marques-Ibanez. 2019. "Determinants of Syndicated Lending in European Banks and the Impact of the Financial Crisis". figshare. https://hdl.handle.net/2134/15844. 


\title{
Determinants of syndicated lending in European banks and the impact of the financial crisis
}

This version: 3 April 2014

\author{
Barry Howcroft ${ }^{\mathrm{a}}$, Alper Kara ${ }^{*, \mathrm{~b}}$, and David Marques ${ }^{\mathrm{c}}$ \\ ${ }^{a}$ School of Business and Economics, Loughborough University, UK \\ ${ }^{\mathrm{b}}$ Hull University Business School, UK \\ ${ }^{\mathrm{c}}$ European Central Bank, Frankfurt, Germany
}

\begin{abstract}
Syndicated lending is a widely practiced alternative to traditional bilateral lending and within Europe the syndicated loan market increased significantly during the 2000s. Using a dataset consisting of 4,166 European banks, the authors examine the factors that determine the bank's willingness to use syndicated lending rather than traditional lending during the period 2000 to 2010 . The paper finds that syndicated lending was an alternative to bilateral loans when banks were targeting growth or looking to utilise potential capital surpluses. Syndicated lending was also used to improve the returns and credit quality of the bank's loan portfolios. However, in the post crisis period, European banks are less interested in syndicated loan markets and larger banks, especially, those with strong capital bases, are refraining from syndicated lending.
\end{abstract}

JEL classification: F3, G2

Keywords: syndicated loans, bilateral lending, financial crisis

\footnotetext{
* Corresponding author: Alper Kara, Hull University Business School, HU6 7RX, UK, e-mail: a.kara@hull.ac.uk; tel.: +44 (0) 1482 463310. Alper Kara and Barry Howcroft would like to thank Nuffield Foundation for the financial support to this work. We would like to thank Phil Molyneux, Yener Altunbas and Blaise Gadanecz for valuable comments on this paper.
} 


\section{Introduction}

The collapses of numerous banks and the losses incurred by others in the recent global financial crisis has, once again, brought banks' lending practices to the forefront of political and academic debate. Many causes have been proposed to explain the crisis and subsequent turmoil but at the centre of these proposals has been the notion that there has been a fundamental change in the banks' business model. In essence, this change has been characterised by a move away from traditional financial intermediation towards financial disintermediation. It has manifested itself in the relative decline in the importance of bank deposits as sources of funds and the increase in importance of public debt markets as major providers of finance for large corporations. Throughout this transformation banks have endeavoured to remain competitive, but many commentators have argued that in doing so they have drifted away from their main role of delegated monitors.

One instrument that allowed such change is syndicated bank loans which involve a group of banks lending together to a single borrower on common terms. For some banks it is an alternative to traditional bilateral lending. Syndicated loans are not new and were considered as an innovation when they first emerged in the 1970s as a way of providing large scale loans to sovereign borrowers. Over the past forty odd years or so the market has ebbed and flowed but the last decade has witnessed a revival and has evolved substantially to provide an alternative to public borrowing for larger corporations. As such, syndicated loans provided the banks with an opportunity to compete with public debt markets in the provision of large scale finance to large borrowers. 
Syndicated lending does not necessarily correspond to what makes banks "special". For example, the literature on financial intermediation emphasises banks distinctiveness, compared to providers of direct finance, as their uniqueness in producing and transferring information and their capacity to mitigate asymmetric information through the bilateral banker-customer relationship (Diamond, 1984, 1991 and Allen, 1990) ${ }^{1}$. In essence, close banker-customer relationships are highly conducive to the banks' efforts to reduce risk, compete more effectively with direct finance markets, create value for borrowers and lenders, and increase net income . $^{2}$ From this perspective, syndicated lending is substantially different from the traditional bank-customer orientation associated with bilateral loans. Specifically, the delegation of responsibility and control by participant banks to arranger banks ostensibly detracts from the banker customer relationship and potentially undermines the creation of value.

${ }^{1}$ The close and unique relationship between banks and borrowers creates benefits such as sharing sensitive information (Bhattacharya and Chiesa, 1995); reducing information asymmetries (Petersen and Rajan, 1994; and Berger and Udell, 1995); monitoring collateral more effectively (Rajan and Winton, 1995); and, adopting a strategy in the pricing of loans in the long term (Berlin and Mester, 1999).

2Lummer and McConnell (1989); Billet et al. (1995) and Preece and Mullineaux (1996) have investigated the signalling effect of borrowing through syndicated lending markets. They provide evidence that capital markets react positively to the announcement of syndicated financing and abnormal returns are observed in a firm's equity. These empirical findings support the arguments of the theoretical literature in banking (see Diamond, 1984, 1991 and Allen, 1990) on the uniqueness of bank in producing and transferring information. 
In a syndicated loan arranger bank(s) are at the core of the syndication arrangement. Participant banks are less active than arrangers in negotiating the loan terms. During the life of the loan they have an "arm's-length" relationship with the borrower and act through the arranger or agent bank (Simons, 1993 and Sufi, 2007). Hence, participant banks rely substantially on arranger banks both before and after the loan issuance. Prior to issuance, participant banks depend on the arranger to evaluate the credit quality of the borrower. After issuance the monitoring of the loan and the relationship with the debtor is often delegated to the arranger banks. Accordingly, the nature of the participant banks role and their relationship with the borrower would appear to be substantially different compared to bilateral loans.

Against this background we investigate the choice of syndicated lending over bilateral lending by participant banks. In particular, we examine the relationship between the financial features of participant banks and the share of syndicated loans in their portfolios. As outlined above, this is an important question because banks are generally regarded as creating value through the explicit banker-customer relationship associated with bilateral lending. Furthermore, there is a gap in the extant literature on the motives of participant banks for becoming involved in syndicated lending. Apart from Altunbaş and Kara (2011), the main focus tends to be on arrangers rather than participant banks (see Pavel and Phillis, 1987; Simons, 1993; Pennachi, 1998; Dennis and Mullineaux, 2000; Panyagometh and Roberts, 2002; and Altunbaş et al., 2005) $)^{3}$ Accordingly, the literature highlights regulatory capital, liquidity constraints,

\footnotetext{
3 Previous studies have also focused on the role of the arranger, their reputation, and possible asymmetric information problems (such as Lee and Mullineux 2001 and Panyagometh and Roberts 2002) and the pricing of syndicated loans in relation to borrower financial characteristics and loan
} 
portfolio diversification, increasing net interest margins and fee income as the main factors effecting the syndication decision.

In this paper we extend the literature in several ways. Firstly, our focus is on participant banks that need to make the decision between close-relationship bilateral loans and "arms-length" syndicated loans. Secondly, unlike earlier studies which examine the participation decision only, we calculate the share of the syndicated loans in banks' loan portfolios and account for the size of lending in relation to banks financial conditions. Thirdly, we study a period between 2000 and 2010 in which the debt and corporate borrowing markets in Europe expanded exponentially until 2007 and subsequently were affected by the global financial crisis. Crucially, the determinants of syndicated lending during the economic expansion and the impact of the financial crisis on banks' choices as to whether or not to make syndicated loans has received little or no academic attention.

Finally, we look at European banks which are rarely studied in this context. The decision to make syndicated loans is more complicated for European banks since Europe has essentially been a bank-orientated system, as opposed to the United States, which is more orientated to capital markets. In fact, European banks are less likely to engage in syndicated lending compared to U.S banks and banks from emerging markets (Gadanecz et al., 2006). Furthermore, the period under analysis is significant as European banking has witnessed important changes in the form of consolidation and internationalisation after the introduction of the euro in 1999, and

terms (such Coleman et al., 2002; Hubbard et al., 2002; Angboza et al., 1998 and Yi and Mullineaux, 2005). 
the introduction of new member states during 2004 and 2007 (Pisani-Ferry and Sapir, 2010). As syndicated loans are predominantly a cross-border lending mechanism, it is interesting to observe these changes through bank lending behaviour in this market.

The data we utilise consists of 4,166 European banks of which 357 were active in the syndicated loan market between 2001 and 2010. Using panel data estimation techniques, we examine the amount of funds allocated to syndicated lending and a range of bank-specific financial characteristics - such as size, liquidity and capital adequacy - that are likely to influence this decision. The remainder of the paper is structured as follows: The next section discusses the structure of syndicated loans and reviews the literature on costs and benefits to banks. Section 3 introduces the methodology and data, and presents the descriptive statistics. Section 4 presents the results and the final section concludes by summarising the main findings of the paper.

\section{Costs and benefits of syndicated lending: A literature review}

In a typical syndicated loan the arranger, who normally has an established relationship with the borrower, first meets the borrower to negotiate and discuss the broad terms of the loan. Subsequently, the arranger will meet with the participants to discuss the details of the loan and establish the timetable and size of commitment for individual participants. In most cases arrangers retain part of the loan on their books with the remaining balance being provided by participants. Once the sell-down has been completed, the arranger and all of the participants sign the loan agreement and the deal becomes active. The arrangement of the syndicated loan, which provides banks with a substantial source of fee income, is typically undertaken by large investment 
banks. Participant banks, on the other hand, are usually geographically diverse and comprise smaller commercial banks with relatively less experience of international lending (Gadanecz et al, 2006). They are not involved in the arrangement, negotiation and setting up of the syndication. Moreover, once the loan has been issued and throughout its duration until maturity, the participant banks have no direct involvement with the borrower. Accordingly, once the loan has been successfully sold down, the arranger normally becomes the agent bank and acts on behalf the participants (Howcroft, 1998).

Once the loan has been issued its subsequent monitoring and the relationship with the borrower are typically delegated to the arranger/agent bank. This is important because the monitoring function and the banker-customer relationship are generally regarded as methods for reducing borrower moral hazard. This consideration raises an additional type of moral hazard problem: as the arranger bears all of the costs associated with the monitoring of the loan, it might be disinclined to share all of the benefits of the relationship with participants (Bharath et al., 2010). Several studies (Simons, 1993, Jones et al. 2005, Panyagometh and Roberts, 2002 and Sufi, 2007) have examined the arranger's role and the associated moral hazard issues and opportunistic behaviour of arrangers. In broad terms these studies have found that arrangers do not exploit information advantages. In fact, the empirical evidence suggests that if the borrower is of low quality and requires high levels of monitoring, they have a tendency to keep larger shares of the loan ${ }^{4}$. On a similar note, Gadanecz

\footnotetext{
${ }^{4}$ Dennis and Mullineaux (2000), Lee and Mullineaux (2001) and Panyagometh and Roberts (2009) have also examined the influence of the arranger's reputation on the success of a loan syndication.
} 
et al. (2012) argue that some costs of syndicated lending from a participant bank's perspective mainly stems from arranger participant relationship. The fact that participant banks rely on the arranger to negotiate and deal with the borrower means that they depend on the arranger to evaluate the borrowers' credit quality. Gadanecz et al. (2012) show that when participant banks have information inferiority in the syndicate, they require higher loan spreads to compensate for the asymmetry, especially, when the borrower is more opaque.

These considerations raise the question that if participant banks are predominantly dependent on arrangers for value creation in syndicated lending, what are the benefits of syndicated lending? A number of studies have investigated the factors that determine the choice of syndicated lending (for example, Pavel and Phillis, 1987; Simons, 1993; Pennachi, 1998; Dennis and Mullineaux, 2000; Panyagometh and Roberts, 2002; Esty and Megginson, 2003; and Altunbas et al., 2005, Sufi, 2007). These studies suggest that syndicated loans can be used by banks to alleviate regulatory capital constraints ${ }^{5}$. For smaller banks participation in a syndicated loan helps to develop new business and diversify their loan portfolio by extending credit to the sort of large borrowers that they would not normally do business with. For larger banks more readily associated with arrangers, the syndication of a large loan is a method of risk management because it effectively spreads the risks of the loan over

\footnotetext{
They find that a syndication is more likely to be successful with a larger loan amount and more participants when the arranger has a good reputation as an arranger in the market.

${ }^{5}$ From a pricing perspective Hubbard et al. (2002) investigate whether capital constrained banks charge higher yield spreads, and argue that the cost of borrowing from capital constrained banks will be higher than from well capitalized banks, particularly for borrowers facing substantial costs in switching to alternative bank lenders because of high information costs.
} 
several lenders. As such, it decreases the lender's exposure to a single borrower but simultaneously allows the lender to maintain an important relationship with the borrower. $^{6}$

Syndicated loans are an effective tool for portfolio diversification (Dennis and Mullineaux, 2001). In this respect, they provide the opportunity for lenders to spread their risks more widely, both in geographic and sectoral terms, without exclusively using their own resources for monitoring and getting to understand the dynamics of a new economic environment. Eichengreen and Mody (2000) and Simon (1993) argue that banks also have a tendency to engage in syndicated lending when they have excess liquidity.

In bilateral lending the associated costs of having a banker customer relationship fall on the individual bank. This consideration has led Armstrong (2003) to suggest that smaller participant banks may be motivated to enter into syndicated loans in order to economize on these costs. Altunbas et al. (2005) and Jones et al. (2005) have argued that for larger credits, in particular, syndicated lending allows arranger banks to leverage the business on the basis of their brand name and worldwide expertise/reputation. Another consideration is that because syndicated loans are publically announced, they might be beneficial as a means of advertising the activities of banks in the financial markets. This is important because having a presence in the

\footnotetext{
${ }^{6}$ Syndicated lending also allows banks to compete more effectively with public debt markets for corporate loans (Jones et al., 2005). The main business of banks, acting as intermediaries between fund suppliers and demanders, has being disrupted by firms choosing direct finance, such as commercial paper or bonds rather than bank loans. Syndicated loans have been an attractive alternative for these financial products, and enable commercial banks to earn spread and fees from such business.
} 
market and more importantly being seen to have a presence can be a key determinant of future business prospects (Howcroft and Solomon, 1985).

As already mentioned, the vast majority of empirical studies on syndicated lending have examined it from the perspective of the arranger bank. For example, Simons (1993) and Jones et al. (2005) focussed on the relationship between the arranger bank's financial features and the share of the syndicated loan retained by these banks. Similarly, Dennis and Mullineaux (2000), Panyagometh and Roberts (2002), Lee and Mullineaux (2004), Altunbas et al. (2005), Sufi (2007) investigated the influence of loan terms and borrower credit quality on the arranger bank's decision to arrange a syndicated loan and the share of the loan retained by the arranger afterwards ${ }^{8}$. Altunbas and Kara (2011) examined the motives of participant banks when joining syndications, however their study, due to data limitations, only examines the choice of syndicated lending and the data period correspond to 1990s.

\footnotetext{
${ }^{7}$ Dennis and Mulliaux (2000) and Panyagometh and Roberts (2002) identify empirically the factors that influence an arranger bank's decision to syndicate a loan and the determinants of the proportion of the loan sold in the event of syndication. They utilize loan characteristics, arranger's financial characteristics, variables related to the opacity of the borrower and information asymmetries as explanatory variables. Altunbaş et al. (2005) employ arranger banks financial characteristics as the main determinants of arranger banks decision to syndicate loans. In contrast, Pavel and Phillis (1987), Simons (1993) and Pennachi (1998) use share of the loans retained (or syndicated) by the arranger banks.

${ }^{8}$ Coleman et al. (2002) and Hubbard et al. (2000) also examine how the capital levels, loan portfolio quality, and liquidity ratios of senior banks influence pricing.
} 
This paper, therefore, attempts to address some of the omissions in the extant literature. Firstly, for the first time we utilise the share of syndicated loans in banks' loan portfolios as a proxy to examine the behaviour of participant banks and the factors that determine their choice of syndicated lending. Secondly, the data relates to quite a remarkable decade during which the international financial markets experienced unprecedented growth and contraction. Thirdly, we focus on European banks during a period when financial market integration was encouraged in Europe. The next section describes the research methodology and discusses the data in more detail.

\section{Methodology, data and descriptive statistics}

\subsection{Model and variables}

In order to investigate the factors that influence and determine a banks involvement in syndicated lending, we ascertain the relative importance of syndicated lending within the loan portfolio for each bank. This was accomplished by comparing the amount of syndicated lending with the size of the total loan portfolio. We then compare this relative measure of syndicated lending to a range of financial characteristics, such as, size of bank, capital constraints, loan portfolio quality, income diversification, cost efficiency and liquidity. These variables were identified from the extant literature and are regarded as important determinants of the allocation of funds by banks (see for example Altunbas et al., 2007 and Goddard et al., 2004). 
Some banks do not regard syndicated lending as a viable business option or simply do not have access to the market. Accordingly, the sample was selected on the basis that it included only those banks that had joined loan syndicates and had access to the market. Because we use banks which already have syndicated loans, there is a potential sample selection problem if the unobserved determinants of share of syndicated loans also affect banks' syndicated loan participation. To correct the selection bias we use Heckman's two-step estimating procedure. In the first step, prior to estimating the main model, the probit model shown below was used to estimate the probability of a bank participating in a syndicated loan or Synd. Synd takes the value of 1 if a bank has participated in loan syndications within a given year and 0 otherwise. This approach is analogous to earlier research by Dennis and Mullineaux (2000), Panyagometh and Roberts (2002), and Altunbaş et al. (2011). These studies employ a dummy dependent variable to model the factors shaping the choice of the syndication decision by arranger banks. In the selection model a sample of 4,166 banks was used but only 357 had been involved in syndicated lending between 2000 and 2010. The selection model is presented below in equation 1:

$$
\begin{aligned}
& \operatorname{Pr}\left(\text { Synd }_{i, t}\right)=\beta_{0}+\beta_{1} \text { Bank size }_{i, t-1}+\beta_{2} \text { Portfolio quality }_{i, t-1}+\beta_{3} \text { Liquidity }_{i, t-1}+ \\
& \beta_{4} \text { Securitisation }_{i, t-1}+\beta_{5} \text { Listed }_{i, t}+\sum_{c=1}^{C-1} \beta_{m} \times{\text { Country of } \text { origin }_{c}+}^{Y-1} \beta_{y=1} \times \text { Year }_{y}+e_{i, t}
\end{aligned}
$$

The variables are described below in detail. We select four main variables, bank size, portfolio quality, liquidity and being active in the securitisation markets (securitisation), which may influence the decision of syndicated lending. We assume that larger banks are more likely to invest elsewhere when their own market is 
saturated and syndicated lending may be an alternative to expand. Additionally, due to sizeable loan amounts in the syndicated loan market only relatively larger banks may take part. A deteriorating loan portfolio quality may prompt banks to look at alternative lending practices and syndicated lending, due to higher quality borrowers in the market, may be an attractive option. Liquidity is also a factor as liquid bank search for alternative assets. Being active in the securitisation market shows the bank's degree of integration with financial markets as well as the motivation to operate beyond "traditional banking" business model. In addition to the main variables, in the selection model we use Listed, to indicate whether a bank is listed on stock exchange. We utilise Listed for identification in the selection equation. We stipulate that being listed on a stock exchange is a signal of the ability to access the wider financial markets in general. Finally, we use dummy variables to control for country of origin and year dummy variables to control for the macroeconomic environment.

Subsequently, in step two the main model was estimated by adding the inverse of Mill's ratio, which is derived from the probit estimate in (1). The share of syndicated loans to total loans (Syndshare) was modelled as a function of the bank i's financial characteristics for the fiscal year $t-1^{9}$. This model estimates the impact of bank financial characteristics on the amount of syndicated loans after the bank's initial decision to enter the market. The model is shown in equation (2), as follows:

\footnotetext{
9 Ideally, one would like to have information from the bank's monthly internal reporting system. However given the yearly frequency of publicly available balance sheet and profit/loss statement information, values at the end of the fiscal year preceding the loan participation decision are the most accurate measure one can use to gauge the interaction between bank characteristics and lending decisions.
} 
Syndshare $_{i, t}=\beta_{0}+\beta_{1}$ Bank size $_{i, t-1}+\beta_{2}$ Capital adequacy $_{i, t-1}+$

$\beta_{3}$ Portfolio quality $_{i, t-1}+\beta_{4}$ Liquidity $_{i, t-1}+\beta_{5}$ NIM $_{i, t-1}+\beta_{6}$ Cost efficiency $_{i, t-1}+$

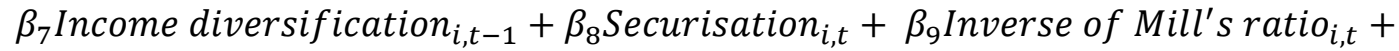

$\sum_{c=1}^{C-1} \beta_{m} \times$ Country of origin $c+\sum_{y=1}^{Y-1} \beta_{n} \times$ Year $_{y}+v_{i, t}$

Variables from (1) and (2) are described as;

Syndshare is the share of loans syndicated and calculated as the percentage of syndicated loans in the bank's total loans portfolio, including bilateral loans.

Banks size is proxied by the natural logarithm of total assets.

Capital adequacy is measured by the ratio of Tier 1 capital to total risk-weighted assets. Banks' loan supply function is directly related to capital constraints.

Loan portfolio quality is measured by the ratio of loan loss provisions to total loans. Loan loss provisions can be thought of as a proxy for loan quality, which can influence lending policies.

Liquidity is proxied by the ratio of securities to total assets and signals the immediate availability of funds to meet loan demand. Saturation in local business' borrowing activity might lead to additional liquid funds in banks. It may also signal the business strategy of the bank in terms of asset diversification.

NIM - net interest margin is an indicator of a bank's performance in its primary business of financial intermediation. Inability to achieve higher NIM in a given year might prompt banks to look for alternative income to boost returns. Syndicated loans widen the potential customer range for banks and introduce the possibility of reaching borrowers in other markets. 
Cost efficiency is measured by the cost to income ratio. As noted in James (1987), banks have a cost advantage when screening, monitoring and transforming information relative to outsiders. Banks' allocation of funds in loan syndications can be thought of as a means of exploiting this cost advantage because these costs are generally borne by the arranger banks.

Income diversification is measured by the ratio of non interest income to total income. The level of non-interest income is an indication of how well a bank is diversified in terms of creating alternative income streams. Depending on the terms of the loan agreement, participants in a syndicated loan can earn a range of different fees $^{10}$.

Securitisation is a dummy variable and takes the value of 1 if the bank securitised any assets in a given year and 0 otherwise.

Inverse of Mill's ratio is derived from the first-step of the estimations, country of origin and year dummy variables are utilised to control for country and macroeconomic effects respectively. In addition to the variables presented in model (2), in alternative specifications we use a dummy variable to proxy for the post financial crisis period and capture banks' behaviour in situations where the screening and monitoring of borrowers became imperative for maintaining performance during the economic downturn.

\footnotetext{
${ }^{10}$ For example, they will typically receive a participation fee for agreeing to join the facility, an annual commitment or facility fee to compensate for the cost of tying up regulatory capital, and a utilisation fee when the funds are drawn by the borrower, etc.
} 


\subsection{Data}

The sample covers the period 2000-2010 and includes information on 4,166 banks of which 357 participated in loan syndications during this period. The sample includes only participant banks and excludes any arrangers of syndicated loans. We also exclude any participant that acted as an arranger in another loan syndicate. The dataset was constructed by combining data from two different commercial data providers: Dealogic Loanware and Thomson One Banker. In constructing the dataset, we first identified the banks that lend through syndications and their participation amounts were derived from the Loanware database. Subsequently we obtained information on the banks' characteristics from the balance sheets and profit and loss accounts contained in the Thomson One Banker. These data resources do not have a unique identifier to match the two databases; hence, all of the data was hand-matched by a visual inspection of bank names.

Our primary interest is to examine the considerations that motivate commercial banks, i.e. banks whose main business is financial intermediation, to choose syndicated lending rather than bilateral lending. Investment banks, which typically act as arrangers in syndicated lending were, therefore, excluded from the sample. This approach was adopted in an endeavour to redress a weakness in the extant literature, which stems from the fact that previous studies (Simons 1993, Dennis and Mullineaux 2002, Jones et al. 2005, Panyagometh and Roberts 2002, and Altunbaş et al. 2005) focus almost exclusively on arranger banks. 
One reason why the literature focuses on arranger banks relates to the lack of information on participant banks. Loanware database provides information related to the share of the loan retained by the arranger but not necessarily by participant banks and does not provide shares of each participant banks for all deals ${ }^{11}$. It is not clearly stated for what percentage of the deals the database provides full information on participant shares. This ratio may depend on the chosen time period. For the sample we collected for this study, we calculated banks' participation amounts utilising both share reporting and non-reporting deals data. For deals where shares are not reported, we calculated each bank's share by dividing the total loan amount to the number of banks participated in the loan.

In Table 1 we detail the features of the data by presenting selected descriptive statistics. In Panel A we report the features of the banks' loan shares. The total number of loan participations by the banks in our sample is 12,878. Bank participation amount is accurately known for 10,334 of these loan shares, which corresponds to approximately 80 percent of the loan share observations. For 2,544 loan share observations we estimate the loan share of each bank by dividing the total loan amount by the total number of banks in the loan syndicate. The mean loan share amount for the two groups (reported and non-reported loan shares) is 21.2 and 20.1 million Euro, respectively. Although the loan participation share is estimated for around 20 percent of the loans, we believe this still leads to a relatively accurate way of calculating the total funds lend through participating syndicated loans, given the limitations of the database. We observe that on average a bank participated into loan

\footnotetext{
${ }^{11}$ Additionally, compared to the number of arranger banks organizing the syndications, the number of participant banks is significantly larger. Due to the reporting method of Loanware database, it is technically a challenging task to identify all the participants in syndications and match these with their respective financial indicators.
} 
syndications 36.1 times within the ten year period which corresponds to 3.6 times per year.

Panel B of Table 1 shows the differences between participant and non participant banks by displaying the mean and the median values for a range of selected ratios. The t-statistics for the mean comparison tests are also presented in the last column of the table. Participant banks account for $8 \%$ of the entire sample. In terms of total assets the participant banks are significantly larger than non-participant banks. Participant banks are also better capitalised. We observe a lower loan loss provision to total loans ratio for participant banks. In terms of income, participant banks operate with significantly lower net interest margins whereas non participant banks have higher non interest income. Additionally, participant banks have lower cost to income ratio compared to non participant banks. Banks are more active in the securitisation market if they participate in syndicated loans. Furthermore, participant banks are more likely to be listed on a stock exchange. In Panel $\mathrm{C}$ we present the distribution of our sample in terms of country of origin and years. Observations from Germany constitute a significant portion of the sample as the banking sector in this country is the largest in Europe. The observations per year are distributed reasonably well within the sample period.

\section{Results}

At the outset of the analysis we estimate models without the selection equation. The results are presented in Table 2. The models are estimated using OLS and OLS with bank specific fixed effects. We run alternative models utilising all sample as well as 
only those banks that were active in the syndicated loan market. As some of these banks in the latter group do not participate in loan syndications on a yearly or regular basis, it provides us with the opportunity to examine the associated changes which occur when their lending behaviour varies throughout the period.

We only interpret the results shown in the last two columns because these models are more robust as they control for bank specific fixed effects. In the penultimate column we present the results of estimations for all observations in the sample. We find that banks lend more through loan syndications when they are large and have higher capital adequacy ratios. The share of syndicated loans in the loan portfolio also increases when banks have higher loan loss provisions and lower net interest margins. In the last column we present results for the model with syndication active banks only. The results are similar to the "all observations" except the coefficient of bank size loses its significance.

\subsection{Main model with selection bias correction}

We estimate the main model using the inverse Mill's ratio (IMR), which is derived from the selection model, to correct the possible selection bias. Results are presented in Table 3. Firstly, we interpret the findings for the selection equation which are presented in the first column. We observe a positive and statistically significant coefficient for bank size and loan portfolio quality. This indicates that larger banks and banks with high loan loss provisions are more likely to participate in loan syndications. Larger banks may use syndicated loan markets as an alternative asset for an already established, and perhaps saturated, loan portfolio. More interestingly, 
it is evident that banks utilise syndicated lending when the quality of the loan portfolio deteriorates. This is related to the fact that the majority of firms borrowing on the syndicated loans market are large credit worthy borrowers. Accordingly, banks that want to increase the overall quality of their loan portfolios would appear to utilise syndicated loans in order to access these low risk customers. Banks that are active in securitisation markets and listed on a stock exchange are also likely to use syndicated lending.

Subsequently in Table 3 we present the results of the main model where the dependent variable is the ratio of syndicated loans to total loans. The models are estimated using OLS with and without fixed effects and the results of alternative specifications, where we include control variables progressively, are shown in five models (from columns two to six). In all specifications, the results shown above remain robust even after adjusting for possible selection bias issues. The findings presented in the last column are also more reliable as we utilise all the control variables with bank specific fixed effects. Hence, in the discussion below we only interpret these results.

We find that asset size is a significant determinant of the share of funds allocated for syndicated lending ${ }^{12}$. As banks get larger they seek alternative investment instruments in order to diversify and grow their asset portfolio. Similarly, as part of this process, they also search for potential customers located outside their domestic markets. This suggests that syndicated lending may be used by participant banks as an initial "stepping stone" for cross border expansion. Moreover, this typically occurs

\footnotetext{
${ }^{12} \mathrm{We}$ also note that the coefficient of this variable changes from negative to positive when we control for year and bank specific fixed effects.
} 
once the banks have reached a certain size and level of activity in the domestic markets. This explanation is based on the fact that syndicated loans are typically extended to large multinational companies. Participation in syndicated loans, therefore, may enable banks to become familiar with international lending practices and enhances their experience of being associated with international companies.

We find that banks lend more through loan syndicates when they have higher capital adequacy. This is contrary to the findings of Simons (1993), Dennis and Mullineaux (2000) and Jones et al. (2000) whose studies found evidence for a significant negative relationship. They found that the capital position of the banks had a significant influence on lending decisions and that as capital ratios declined banks were more likely to become involved in syndicated lending. Simons (1993) rationalises this finding by arguing that banks, which are constrained by regulatory capital considerations might be reluctant to place additional pressure on their balance sheets. Rather than engaging in large bilateral lending they spread their exposure by syndicating a portion of the loan ${ }^{13}$. However, these findings are based on evidence derived from arranger banks which are typically investment banks. As such, the nature of their core business and the structure of their balance sheets are quite different compared to the commercial banks that act as participants in syndicated lending. Additionally, unlike the above studies, we utilise a risk weighted capital adequacy variable. Accordingly, the findings in this paper support the view that participants only become involved in syndicated lending if they have sufficient capital to warrant the exposure. The results also show that banks with high risk adjusted

\footnotetext{
${ }^{13}$ They might also tend to boost their capital adequacy ratios by syndicating part of their existing loan portfolios.
} 
capital levels allocate more funds to syndicated lending in comparison to bilateral lending. Given that in loan syndications participant banks have a relatively distant relationship with the borrowers - in comparison to the arranger banks, the findings indicate that banks with weaker capital adequacy levels are more likely to prefer bilateral lending. This strategy may avail these banks to be more in control of pre lending screening and post lending monitoring of the borrowers. In other words strong levels of regulatory capital increases banks' capacity to use alternative instruments and markets for business ${ }^{14}$.

The ratio of loan loss provisions to total loans exhibits a positive relationship with the level of syndicated lending in the banks' portfolios. This finding suggests that banks attempt to diversify non-performing bilateral lending portfolios by increasing the share of syndicated lending in the overall portfolio. This may relate to the fact that the majority of firms borrowing on the syndicated loans market are large credit worthy borrowers. Accordingly, banks that want to increase the overall quality of their loan portfolios could utilize syndicated loans in order to access these sorts of customers.

\footnotetext{
${ }^{14}$ In relation to the impact of capital adequacy on the choice of syndicated lending, we also tried to assess the possible impact of regulatory changes on capital and credit-risk assessment introduced by Basel II during the period of the study. In Europe Basel II was implemented starting from January 2007. Compared to Basel I, Basel II provided a more risk-sensitive methodology for the measurement of regulatory capital which allowed banks to adjust capital more accurately in relation to different credit risk levels. Basel II had the potential to make syndicated loans more attractive to borrowers and lenders alike. Given that syndicated loan borrower are less risky, bank could have less spare capital for these types of loans. For example FDIC (2003) suggested that Basel II would lead to a reduction in risk-based capital requirements for syndicated loans in the range of 10 to 40 percent. Such a reduction certainly makes funding cheaper for companies in syndicated loan markets. In unreported results, we examine the interaction between the year dummy variables (used for control variables) and the relative size of the syndicated loan portfolio. We find that banks were more likely to have larger syndicated loan portfolios during the period preceding the financial crisis between 2003 and 2006 . We do not detect a significant increase for 2007 and the period after. It is impossible to conclude that the expected impact of Basel II on syndicated lending is not observed because other factors caused by the financial crisis had a distressing effect on the European economy and banks. We believe what we observe is heavily influence by the dynamics of these extraordinary times. However, for further research, it would be interesting to look at the impact of Basel III regulatory framework on syndicated lending once the banking environment returns to normal in Europe.
} 
One variable that becomes significant with the selection bias controlled models is securities to total assets for which we find a negative relationship with the share of syndicated loans in the banks' loan portfolio. A larger securities portfolio, which would normally incorporate a range of assets, would typically be dominated by government bonds and interbank deposits, and would provide the banks with additional flexibility and liquidity. A larger securities portfolio could also be signalling that participant banks are concentrating less on their traditional business of domestic financial intermediation, and diversifying into other assets.

Compared to bilateral loans, syndicated loans have a greater liquidity advantage via the secondary syndicated loan market. Secondary markets provide banks with the option to liquidate their syndicated loans and during the 2000 s the volume of secondary syndicated loan market activity increased greatly. Our findings supports Dennis and Mullineaux (2001) argument that banks' use syndicated lending as an alternative to securities investments to diversify their assets, perhaps for more liquidity. In other words, syndicated lending is seen as a substitute to other liquid securities. A share in a syndicated loan may not be as liquid as a government bond; however, it is substantially more liquid than a bilateral loan ${ }^{15}$.

The analysis indicates a significant negative relationship between net interest margin and the level of syndicated lending. The net interest margin measures how successful a bank is in generating income from financial intermediation. The results suggest that

\footnotetext{
${ }^{15}$ Conversely, in untabulated results, we find a negative relationship between size of loan portfolio and the share of syndicated loans in banks' portfolio. Proportionally, banks place less of their funds in syndicated lending if they have a large loan portfolio. This finding strengthens our argument that syndicated lending is generally more likely to be regarded as an alternative asset to securities than to bilateral lending.
} 
banks that have high interest margins are less interested in syndicated lending. On the other hand, banks that are not generating enough interest income from their primary business might choose syndicated lending in order to increase their level of income. Syndicated lending is conducive to achieving this objective because it provides an opportunity to acquire exposure to new customers such as those in newly emerged markets and alternative industries where higher margins can be achieved. Banks may also prefer syndicated lending because it takes time to penetrate new markets and acquire the expertise to lend bilaterally.

We do not find consistently significant coefficients to provide empirical evidence for Armstrong's (2003) cost effectiveness (measured for cost to income ratio) argument. Syndicated lending may be a means for extending new loans in a cost effective way via the sharing of the administrative and monitoring costs normally associated with large scale corporate lending. However, dependence on arranger banks for propriety information about the borrower does introduce the possibility of information asymmetries within the syndicate. In turn, the associated moral hazard problems have the potential to introduce additional hidden costs. Coefficients of non interest income to revenue and securitisation are also insignificant. We also find that the coefficient of IMR in OLS models is significant, which signals the need to correct for selection bias. The significance disappears in OLS with FE specification.

\subsection{The impact of the financial crisis}

To gauge the impact of the financial crisis on banks' choice of syndicated lending, we include a dummy variable proxying the post crisis period into the analysis. The 
results are presented in Table 4 . Introducing the variable does not alter the main findings discussed above, especially for the most robust model presented in the last column. We find that the coefficient of the post crisis dummy variable is negatively and significantly related to syndicated lending activity and the result is consistent in all models. It is evident that banks reduced the share of syndicated lending in their loan portfolios after the financial crisis.

Subsequently, we estimate the main model for the post crisis period only and examine the changes of bank behaviour towards syndicated lending after the financial crisis. The results are presented in Table 5 and reveal that post crisis some of the determinants of syndicated lending that we observed above lose their significance. Loan loss provisions remains positively related to the share of syndicated lending in banks' loan portfolio. Accordingly, in the post crisis period syndicated lending remained as a viable method of lending to more credible borrowers and as a way of diversifying the non-performing loan portfolio with high quality credit.

However, banks with higher capital levels allocated fewer funds to syndicated lending in the post crisis era. This is the opposite of our findings above. It is plausible that banks that maintained higher levels of capital after the crisis faced fewer losses, either because of being risk averse or having a diversified loan portfolio. In addition, these banks also decreased their level of post crisis syndicated relative to their share of bilateral lending. This may be reflecting increasing asymmetric information costs between participants in the financial markets after the crisis, which lead to more conservative bank lending practises. We also observe that large banks allocate fewer funds to syndicated lending and concentrate more on bilateral banking relationships in 
the post financial crisis period. This may be a reflection of dropping volumes in the syndicated loan market after the crisis and an attempt to reduce risks by nurturing closer relationships with borrowers via bilateral lending.

Reduction in syndicated lending may have a number of explanations related to both supply and demand side of the market. Supply side factors may, for example, relate to increase in asymmetric information in the financial markets during the crisis. Loan syndicates are particularly prone to this because they have a multi-party structure with participant banks relying on arranger banks. Hence, compared to bilateral loans, where a lender only needs to manage information asymmetries related to the borrower, another facet of information asymmetries exist between the participant banks and arrangers of the syndicate. During the financial crisis information asymmetries, especially in Europe, increased between the market participants in the financial markets. In an uncertain environment banks may, therefore, have reduced syndicated lending activity and shifted to bilateral lending where they have more control over the information.

Secondly, because borrowers in the syndicated loan markets have a more international profile, there is the possibility that the greater uncertainty associated with cross border lending made syndicated lending an unattractive choice for banks during the global economic slowdown. In other words, banks continued to lend but more to their domestic markets ${ }^{16}$.

\footnotetext{
${ }^{16}$ A simple analysis of looking at the size of the loan portfolios of the banks in our sample over time shows that banks' overall loan portfolios in relation to total assets remained at similar levels in the post crises period.
} 
Looking at the demand side, the reduced importance of syndicated lending in bank portfolios might be reflecting the simple fact that activity volume in the global syndicated loan market declined, especially in 2008 and 2009, as demand from corporations reduced. For example, syndicated loans are particularly preferred for financing corporate $\mathrm{M} \& \mathrm{~A}$ and project finance transactions due to the considerably sizable financing that the market can provide in a single transaction ${ }^{17}$. These are two corporate activities that soar during an economic upturn and plummet in the periods of economic slowdown.

These findings fit well with the current ongoing issues in European banking. Navaretti et al. (2010) argues that multinational banks had been growing fast since the mid to late 1990s but within the European Union many of these had to be bailed out or supported with public funds after the crisis. Many of these multinational banks were using syndicated loan markets to expand their cross-border business. In fact the syndicated loan markets were regarded as a vehicle for the integration of financial markets and financial intermediation within Europe. However, this integration process abruptly stalled with the advent of the financial crisis and problems associated with a marked loss of confidence in the European banking system (Veron 2012).

\section{Conclusion}

The paper has investigated the factors that influence European banks when choosing between syndicated lending and bilateral lending. This decision is complicated because in syndicated lending participant banks are ostensibly less active than when

\footnotetext{
${ }^{17}$ According to Altunbas et al. (2006) around 27\% of the syndicated loans are used for M\&A or project financing by companies.
} 
they are involved in bilateral lending and they have an "arm's length" relationship with the borrower. We also examined the impact of the recent financial crisis on bank behaviour in the syndicated loan markets.

We draw several conclusions regarding the choice of syndicated lending by European banks. Firstly, we observed that in Europe larger banks that are more integrated with the financial markets, such as those that are listed in stock exchanges or active in the securitization markets, and have higher regulatory capital are active in the syndicated loan markets. Secondly, we find that syndicated lending is an inferior alternative to bilateral loans when banks are looking for growth or to utilise potential capital. From this perspective, however, syndicated lending is regarded as an alternative diversification strategy compared to other more liquid assets. Thirdly, we find that syndicated lending is used by banks to improve the performance of their loan portfolios, both in terms of returns and quality.

With regard to the financial crisis, this has had a negative impact on the volume of syndicated loans. Post crisis, European banks, especially larger ones, have reduced the share of syndicated lending in their loan portfolios. Moreover, with the continuing uncertainty about European economies, banks with excess capital have become more conservative and have placed more emphasis on traditional bilateral lending. Given that syndicated loan markets constitutes one third of all international financing in capital markets around the world and provide a vital funding source for larger companies in Europe, it is imperative for European policy makers to examine the factors that led to this fall in appetite for syndicated loans. It is difficult to exactly 
pinpoint the reasons behind this fall due to the ongoing restructuring of the banking sector and financial markets.

From a policy perspective alternative explanations may have different implications. If the reduction is a supply side phenomenon stemming from increased information asymmetries between banks, leading to more conservative lending practices, then restoring confidence to the financial system may reverse this trend. If syndicated lending became less attractive due to its cross border nature then the drop in syndicated lending may be an outcome of conservative lending to domestic markets during the uncertain economic environment between 2007 and 2010. The drop in volume may also be an early sign of national regulatory policies where more domestic lending is encouraged. Hence, policy makers seem to be achieving targets if this is the case.

Still another factor may be the efforts to develop a regulatory approach on an international scale, outlined in Basel III framework, to minimize the effects of interconnectedness among systemically important banks, which transmitted shocks across the financial systems and economies in the crisis. Given the international nature of syndicated loans, inevitably, such regulatory policies may have an effect on the supply side of the syndicated loan market. It is still too early to assess the impact of such regulation on syndicated lending; however, for further research, it would be interesting to look at the impact of Basel III regulatory framework on syndicated loan markets. If the drop in loan volumes is more associated with the demand side then the market should lift up once more economic growth is observed in Europe. 


\section{References}

Allen, F., Gale, D., 1997. Financial markets, intermediaries, and intertemporal smoothing. Journal of Political Economy 105, 523-546.

Altunbaş, Y., Kara, A., Marques, D., 2010. Large Debt Financing: Syndicated Loans versus Corporate Bonds. European Journal of Finance 16, 437-458.

Altunbaş, Y., Gadanecz, B., Kara, A., 2005. Key factors affecting internationally active banks' decisions to participate in loan syndications. Applied Economic Letters $12,249-253$

Altunbaş, Y., Kara, A., 2011. Why do banks join loan syndications? The case of participant banks. The Service Industries Journal 31, 1063-1074

Altunbaş, Y., Carbo, S., Gardener, E.P.M., Molyneux, P., 2007. Examining the Relationship between capital, risk and efficiency in European banking. European Financial Management 13, 49-70

Altunbaş, Y., Gadanecz, B., Kara, A., 2006. Syndicated Loans: A Hybrid of Relationship Lending and Publicly Traded Debt. Palgrave Macmillan, New York, $256 \mathrm{pp}$

Angbazo, L. A., Mei, J., Saunders, A., 1998. Credit spreads in the market for highly leveraged transaction loans, Journal of Banking and Finance 22, 1249-1282.

Armstrong, J., 2003. Syndicated loan market: developments in the north american context. Bank of Canada Working Paper, No: 2003-15.

Bharath, S., Dahiya, S., Saunders, A., Srinivasan, A., 2010. Lending relationships and loan contract terms. Review of Financial Studies Rev 24, 1141-1203.

Berger, A., Udell, G., 1995. Relationship lending and lines of credit in small firm finance. Journal of Business 68, 351-381. 
Berlin, M., Mester, L. J., 1992. Debt covenants and renegotiations. Journal of Financial Intermediation 2, 95-133.

Bhattacharya, S., Chiesa, G., 1995. Proprietary information, financial intermediation and research incentives. Journal of Financial Intermediation 4, 328-357.

Billet, M., Flannery, M., Garfinkel, J., 1995. The effect of lender identity on a borrowing firm's equity return. Journal of Finance 50, 699-718.

Coleman, A.D.F., Esho, N., Sharpe, I.G., 2002. Do Bank Characteristics Influence Loan Contract Terms. APRA Working Paper, February

Dennis, S.A., Mullineaux, D.J., 2000. Syndicated loans. Journal of Financial Intermediation 9, 404-426.

Diamond, D., 1984. Financial intermediation and delegated monitoring. Review of Economic Studies 51, 393-414.

Diamond, D., 1991. Monitoring and reputation: The choice between bank loans and directly placed debt. Journal of Political Economy 99, 689-21.

Esty, B., Megginson, W., 2003. Creditor rights, enforcement, and debt ownership structure: Evidence from the global syndicated loan market. Journal of Financial and Quantitative Analysis 38, 37-59.

Federal Deposit Insurance Corporation, 2003. Risk-Based Capital Requirements for Commercial Lending: The Impact of Basel II. FYI Series. Available at http://www.fdic.gov/bank/analytical/fyi/2003/042103fyi.html

Gadanecz, B., Kara, A., Molyneux, P., 2012. Asymmetric information among lenders and the value of repeat lending. Journal of International Financial Markets, Institutions and Money 22, 913-935. 
Goddard, J., Molyneux, P. and Wilson, J.O.S., 2004. The profitability of European banks: A cross-sectional and dynamic panel analysis. The Manchester School $72,363-381$

Howcroft, B., Solomon, C., 1985. Syndicated Lending By Banks. Bangor Occasional Papers in Economics 22, University of North Wales.

Howcroft, J.B., 1998. International Bank Syndicated Lending: some practical and legal issues. Accounting and Business Review, 5, 123-140

Hubbard, G.R., Kuttner, N.K. and Palia D.N., 2002. Are there bank effects in borrowers' costs of funds? Evidence from a matched sample of borrowers and banks. Journal of Business 75, 559-81.

James, C., 1987. Some evidence on the uniqueness of bank loans. Journal of Financial Economics 19, 217-235

Jones, J., Lang, W., Nigro, P., 2005. Agent bank behavior in bank loan syndications. Journal of Financial Research 28, 385-402.

Lee, S.W., Mullineaux, D.J., 2001. The size and composition of commercial lending syndicates. University of Kentucky mimeograph, available at www.ssrn.com.

Lummer, S.L., McConnel, J.J., 1989. Further evidence on the bank lending process and the capital market response to bank loan agreements. Journal of Financial Economics 25, 99-122

Navaretti, G.B., Calzolari, G., Pozzolo, A.F., Levi, M., 2010. Multinational banking in Europe - financial stability and regulatory implications: lessons from the financial crisis. Economic Policy 25, 705-753

Panyagometh, K., Roberts, G.S., 2002. Private information, agency problems and determinants of loan syndications: Evidence from 1987-1999. Working Paper, York University, Canada 
Pavel, C., Phillis, D., 1987. Why banks sell loans: an empirical analysis. Federal Reserve Bank of Chicago, 145-165.

Pennachi, G., 1988. Loan sales and the cost of bank capital. Journal of Finance 43, $375-396$

Petersen, M., Rajan, R., 2004. The benefits of lending relationships: evidence from small business data. Journal of Finance 49, 3-37

Pisani-Ferry, J., Sapir, A., 2010. Banking crisis management in the EU: an early assessment, Economic Policy 25, 341-373

Preece, D., Mullineaux, D., 1996. Monitoring, loan renegotiability and firm value: The role lending syndicates. Journal of Banking and Finance 20, 577-593.

Rajan, R. G., Winton, A., 1995. Covenants and collateral as incentives to monitor. Journal of Finance 50, 1113-1146.

Simons, K., 1993. Why do banks syndicate loans? New England Economic Review, Federal Reserve Bank Boston, January, 45-52.

Sufi, A., 2007. Information asymmetry and financing arrangements: Evidence from syndicated loans. Journal of Finance 17, 629-668. 
Table 1

Descriptive Statistics

Panel A displays descriptive statistics and information on banks' share on syndicated loan participations. Panel B reports mean, median, standard deviation, minimum and maximum value of financial features of syndicated loan participant and non-participant banks between 2000 and 2010 . T-statistics for mean comparison tests are presented in the last column. Panel C displays the distribution of observations per country and year.

Panel A

\begin{tabular}{lccc}
\hline \multicolumn{1}{c}{ Description } & $\begin{array}{c}\text { Loan share } \\
\text { reported }\end{array}$ & $\begin{array}{c}\text { Loan share not } \\
\text { reported }\end{array}$ & Total \\
\hline \hline Number of syndicated laon participations & 10334 & 2544 & 12878 \\
Mean number of syndicated loan participations per bank & 28.9 & 7.1 & 36.1 \\
Mean number of syndicated loan participations per bank per year & 2.9 & 0.7 & 3.6 \\
Mean loan share amount (million Euro) & 21.2 & 20.1 & 20.7 \\
Median loan share amount (million Euro) & 12.1 & 8.7 & 11.4 \\
Standard deviation of loan share amount & 18.9 & 23.8 & 21.4 \\
Minimun loan share amount (million Euro) & 1.0 & 1.0 & 1.0 \\
Maximum loan share amount (million Euro) & 78.5 & 114.4 & 114.4 \\
\hline
\end{tabular}

\section{Panel B}

\begin{tabular}{|c|c|c|c|c|c|c|c|c|c|c|c|}
\hline \multirow[b]{2}{*}{ Variables } & \multicolumn{5}{|c|}{ Syndicated loan participants } & \multicolumn{5}{|c|}{ Non-participants } & \multirow{2}{*}{\begin{tabular}{|c|}
$\begin{array}{c}\text { Means } \\
\text { comparison }\end{array}$ \\
P-value \\
\end{tabular}} \\
\hline & Mean & Median & St. dev. & Min & Max & Mean & Median & St. dev. & Min & Max & \\
\hline Total assets (million Euro) & 50378 & 8012 & 130751 & 108 & 931335 & 5573 & 1657 & 35484 & 93 & 436446 & 0.000 \\
\hline Tier 1 capital to total risk-weighted assets & 7.73 & 7.37 & 3.07 & 1.19 & 17.24 & 6.81 & 5.95 & 2.92 & -0.47 & 16.11 & 0.000 \\
\hline Loan loss provisions to total loans & 0.74 & 0.51 & 0.58 & 0.00 & 3.72 & 0.84 & 0.65 & 0.67 & 0.00 & 4.68 & 0.000 \\
\hline Securities to total assets & 32.84 & 29.12 & 30.64 & 0.34 & 62.34 & 33.31 & 31.82 & 34.61 & 0.00 & 71.63 & 0.555 \\
\hline Net interest margin & 2.12 & 2.13 & 0.81 & -0.01 & 3.69 & 2.69 & 2.67 & 0.76 & -1.87 & 4.87 & 0.000 \\
\hline Cost to income ratio & 61.50 & 61.40 & 14.12 & 5.91 & 86.82 & 69.21 & 69.51 & 12.95 & 2.10 & 117.26 & 0.000 \\
\hline Non-interest income to revenue & 1.98 & 1.59 & 1.76 & -2.83 & 8.67 & 4.45 & 2.73 & 4.94 & -4.83 & 46.87 & 0.000 \\
\hline Securitisation active & 0.07 & 0.00 & 0.25 & 0.00 & 1.00 & 0.00 & 0.00 & 0.04 & 0.00 & 1.00 & 0.000 \\
\hline Listed in the stock exchange & 0.12 & 0.00 & 0.33 & 0.00 & 1.00 & 0.02 & 0.00 & 0.15 & 0.00 & 1.00 & 0.000 \\
\hline Syndicated loans to total loans & 0.023 & 0.016 & 0.035 & 0.001 & 0.272 & & & & & & \\
\hline Number of observations & 1998 & & & & & 24301 & & & & & \\
\hline Number of banks & 357 & & & & & 3809 & & & & & \\
\hline
\end{tabular}

\section{Panel C}

\begin{tabular}{|c|c|c|c|c|c|c|}
\hline \multirow[b]{2}{*}{ Country of origin } & \multicolumn{2}{|c|}{ Syndicated loan participants } & \multicolumn{2}{|c|}{ Non-participants } & & \\
\hline & $\begin{array}{c}\text { Number of } \\
\text { banks }\end{array}$ & $\begin{array}{c}\text { Number of } \\
\text { observations }\end{array}$ & $\begin{array}{c}\text { Number of } \\
\text { banks }\end{array}$ & $\begin{array}{c}\text { Number of } \\
\text { observations }\end{array}$ & \multicolumn{2}{|c|}{$\begin{array}{c}\text { Yearly frequency of } \\
\text { observations }\end{array}$} \\
\hline Austria & 24 & 168 & 245 & 1,718 & 2000 & 2,113 \\
\hline Belgium & 10 & 56 & 49 & 177 & 2001 & 2,024 \\
\hline Denmark & 9 & 67 & 100 & 557 & 2002 & 1,927 \\
\hline Finland & 5 & 25 & 14 & 46 & 2003 & 1,796 \\
\hline France & 37 & 208 & 305 & 1,695 & 2004 & 1,831 \\
\hline Germany & 39 & 344 & 1,938 & 15,012 & 2005 & 2,013 \\
\hline Greece & 9 & 49 & 15 & 61 & 2006 & 2,885 \\
\hline Ireland & 3 & 16 & 9 & 20 & 2007 & 2,982 \\
\hline Italy & 72 & 323 & 607 & 2,574 & 2008 & 3,003 \\
\hline Luxembourg & 23 & 102 & 62 & 249 & 2009 & 2,864 \\
\hline Netherlands & 12 & 68 & 49 & 180 & 2010 & 2,861 \\
\hline Portugal & 13 & 57 & 38 & 126 & & \\
\hline Spain & 71 & 378 & 109 & 422 & & \\
\hline Sweden & 2 & 7 & 87 & 525 & & \\
\hline United Kingdom & 28 & 130 & 182 & 939 & & \\
\hline Total & 357 & 1998 & 3809 & 24301 & & \\
\hline
\end{tabular}




\section{Table 2}

Determinants of share of syndicated loans in banks' loan portfolio

This table presents coefficient estimates for OLS regressions on the share of syndicated loans in banks' loan portfolios. Dependent variable equals to the amount of syndicated loans in bank's portfolio divided by total loans. Bank size is measured by size log of total assets. Capital adequacy is measured by Tier 1 capital to total risk-weighted assets. Loan portfolio quality is measured by the ratio of loan loss provisions to loans. Liquidity is measured by securities to total assets. Net interest margin is the difference between interest income and interest expense divided by average earning assets. Cost efficiency is measured by cost to income ratio. Securitisation takes the value of 1 if the bank is active in the securitization market and 0 otherwise. Listed bank is a dummy variable taking the value of 1 if the bank is listed at a stock exchange and 0 otherwise. We control for macroeconomic environment with dummy variables for years between 2001 and 2010. Country of origin is controlled for with a set of dummy variables. Robust standard errors are reported in parenthesis. ***, ** and * represents significance levels at $1 \%, 5 \%$ and $10 \%$, respectively. Lagged variables $(t-1)$ are denoted with *.

\begin{tabular}{|c|c|c|c|c|c|c|c|c|}
\hline & \multicolumn{4}{|c|}{ OLS } & \multicolumn{4}{|c|}{ OLS with FE } \\
\hline & \multicolumn{2}{|c|}{ All sample } & \multicolumn{2}{|c|}{$\begin{array}{c}\text { Syndication active } \\
\text { banks }\end{array}$} & \multicolumn{2}{|c|}{ All sample } & \multicolumn{2}{|c|}{$\begin{array}{c}\text { Syndication active } \\
\text { banks }\end{array}$} \\
\hline & Coeff. & Std. err. & Coeff. & Std. err. & Coeff. & Std. err. & Coeff. & Std. err. \\
\hline Log total assets & 0.001 & 0.000 & 0.004 & $0.001 * * *$ & 0.001 & $0.000 *$ & 0.003 & 0.001 \\
\hline Tier 1 capital to total risk-weighted assets & 0.023 & $0.002 * * *$ & 0.259 & $0.003 * * *$ & 0.055 & $0.006 * * *$ & 0.455 & $0.061 * * *$ \\
\hline Loan loss provisions to total loans ${ }^{\ddagger}$ & 0.089 & $0.015 * * *$ & 1.111 & $0.019 * * *$ & 0.089 & $0.013 * * *$ & 1.166 & $0.175 * * *$ \\
\hline Securities to total assets & 0.000 & 0.003 & -0.116 & 0.018 & -0.005 & 0.003 & -0.108 & 0.041 \\
\hline Net interest margin & -0.001 & $0.000 * * *$ & -0.013 & $0.045 * * *$ & -0.001 & $0.000 * * *$ & -0.020 & $0.004 * * *$ \\
\hline Cost to income ratio & -0.001 & $0.001 *$ & -0.005 & 0.001 & 0.000 & 0.001 & -0.018 & 0.012 \\
\hline Non interest income to revenue & -0.031 & 0.001 & 0.025 & 0.006 & 0.000 & 0.001 & -0.001 & 0.005 \\
\hline Securitisation active & 0.006 & $0.002 * * *$ & 0.006 & 0.001 & -0.002 & 0.002 & -0.002 & 0.009 \\
\hline Constant & 0.003 & 0.004 & 0.135 & 0.062 & -0.004 & 0.006 & 0.070 & 0.077 \\
\hline \multicolumn{9}{|l|}{ Control variables } \\
\hline Country of origin & Yes & & Yes & & & & & \\
\hline Year & Yes & & Yes & & Yes & & Yes & \\
\hline R-square & 0.02 & & 0.14 & & 0.01 & & 0.09 & \\
\hline F-test (p-values) & 0.00 & & 0.00 & & 0.00 & & 0.00 & \\
\hline Number of observations & 26,299 & & 1,998 & & 26,299 & & 1,998 & \\
\hline Number of groups & & & & & 4,166 & & 357 & \\
\hline
\end{tabular}




\section{Table 4}

The impact of the financial crises on the choice of syndicated lending

This table presents coefficient estimates for OLS regressions on the share of syndicated loans in banks' loan portfolios. Dependent variable equals to the amount of syndicated loans in bank's portfolio divided by total loans. Bank size is measured by size log of total assets. Capital adequacy is measured by Tier 1 capital to total riskweighted assets. Loan portfolio quality is measured by the ratio of loan loss provisions to loans. Liquidity is measured by securities to total assets. Net interest margin is the difference between interest income and interest expense divided by average earning assets. Cost efficiency is measured by cost to income ratio. Securitisation takes the value of 1 if the bank is active in the securitization market and 0 otherwise. Listed bank is a dummy variable taking the value of 1 if the bank is listed at a stock exchange and 0 otherwise. Post crisis period takes the value of 1 for the years between 2008 and 2010 and 0 otherwise. We control for macroeconomic environment with dummy variables for years between 2001 and 2010. Country of origin is controlled for with a set of dummy variables. Robust standard errors are reported in parenthesis. $* * *, * *$ and * represents significance levels at $1 \%, 5 \%$ and $10 \%$, respectively. Lagged variables $(t-1)$ are denoted with *.

\begin{tabular}{|c|c|c|c|c|c|c|c|c|}
\hline & \multicolumn{4}{|c|}{ OLS } & \multicolumn{4}{|c|}{ OLS with FE } \\
\hline & Coeff. & Std. err. & Coeff. & Std. err. & Coeff. & Std. err. & Coeff. & Std. err. \\
\hline Log total assets & 0.005 & $0.001 * * *$ & 0.010 & $0.003 * * *$ & 0.001 & 0.005 & 0.002 & 0.006 \\
\hline Tier 1 capital to total risk-weighted assets & 0.253 & $0.027 * * *$ & 0.243 & $0.027 * * *$ & 0.343 & $0.053 * * *$ & 0.345 & $0.053 * * *$ \\
\hline Loan loss provisions to total loans & 1.081 & $0.181 * * *$ & 1.064 & $0.181 * * *$ & 1.152 & $0.169 * * *$ & 1.159 & $0.169 * * *$ \\
\hline Securities to total assets & -0.146 & $0.040 * * *$ & -0.136 & $0.041 * * *$ & -0.130 & $0.036 * * *$ & -0.140 & $0.039 * * *$ \\
\hline Net interest margin & -0.013 & $0.002 * * *$ & -0.013 & $0.002 * * *$ & -0.016 & $0.004 * * *$ & -0.016 & $0.004 * * *$ \\
\hline Cost to income ratio & -0.007 & 0.009 & -0.007 & 0.009 & -0.017 & 0.012 & -0.016 & 0.012 \\
\hline Non interest income to revenue & 0.000 & 0.006 & -0.001 & 0.006 & -0.001 & 0.005 & -0.001 & 0.005 \\
\hline Securitisation active & 0.007 & 0.007 & -0.016 & 0.012 & -0.002 & 0.009 & 0.014 & 0.022 \\
\hline Post crisis period & -0.013 & $0.004 * * *$ & -0.012 & $0.004 * * *$ & -0.013 & $0.004 * * *$ & -0.012 & $0.004 * * *$ \\
\hline Inverse Mill's ratio & & & -0.111 & $0.056 * *$ & & & 0.097 & 0.122 \\
\hline Constant & 0.189 & $0.044 * * *$ & 0.305 & $0.073 * * *$ & 0.136 & $0.065 * *$ & 0.050 & 0.126 \\
\hline \multicolumn{9}{|l|}{ Control variables } \\
\hline Country of origin & Yes & & Yes & & & & & \\
\hline R-square & 0.13 & & 0.14 & & 0.08 & & 0.08 & \\
\hline F-test (p-values) & 0.00 & & 0.00 & & 0.00 & & 0.00 & \\
\hline Number of observations & 1,998 & & 1,998 & & 1,998 & & 1,998 & \\
\hline Number of groups & & & & & 357 & & 357 & \\
\hline
\end{tabular}




\section{Table 5}

Determinants of share of syndicated loans in banks' loan portfolio post financial crisis

This table presents coefficient estimates for OLS regressions on the share of syndicated loans in banks' loan portfolios. Dependent variable equals to the amount of syndicated loans in bank's portfolio divided by total loans. Bank size is measured by size log of total assets. Capital adequacy is measured by Tier 1 capital to total riskweighted assets. Loan portfolio quality is measured by the ratio of loan loss provisions to loans. Liquidity is measured by securities to total assets. Net interest margin is the difference between interest income and interest expense divided by average earning assets. Cost efficiency is measured by cost to income ratio. Securitisation takes the value of 1 if the bank is active in the securitization market and 0 otherwise. Listed bank is a dummy variable taking the value of 1 if the bank is listed at a stock exchange and 0 otherwise. We control for macroeconomic environment with dummy variables for years between 2001 and 2010. Country of origin is controlled for with a set of dummy variables. Robust standard errors are reported in parenthesis. ***,** and * represents significance levels at $1 \%, 5 \%$ and $10 \%$, respectively. Lagged variables $(t-1)$ are denoted with ${ }^{*}$.

\begin{tabular}{|c|c|c|c|c|c|c|}
\hline & \multicolumn{4}{|c|}{ OLS } & \multicolumn{2}{|c|}{ OLS with FE } \\
\hline & Coeff. & Std. err. & Coeff. & Std. err. & Coeff. & Std. err. \\
\hline Log total assets ${ }^{\ddagger}$ & -0.003 & $0.001 * * *$ & -0.008 & $0.003 * * *$ & -0.029 & $0.014 * *$ \\
\hline Tier 1 capital to total risk-weighted assets & 0.021 & 0.026 & 0.010 & 0.027 & -0.123 & $0.063 *$ \\
\hline Loan loss provisions to total loans & 0.450 & $0.131 * * *$ & 0.441 & $0.131 * * *$ & 0.263 & $0.139 *$ \\
\hline Securities to total assets & 0.024 & 0.039 & 0.035 & 0.040 & 0.016 & 0.059 \\
\hline Net interest margin & -0.001 & 0.002 & -0.001 & 0.002 & -0.004 & 0.003 \\
\hline Cost to income ratio & 0.000 & 0.007 & 0.000 & 0.007 & -0.004 & 0.008 \\
\hline Non interest income to revenue & 0.000 & 0.003 & 0.000 & 0.003 & -0.001 & 0.003 \\
\hline Securitisation active & 0.005 & 0.005 & -0.008 & 0.009 & -0.018 & 0.030 \\
\hline Inverse Mill's ratio & & & -0.080 & $0.046^{*}$ & -0.120 & 0.173 \\
\hline Constant & 0.027 & 0.041 & 0.112 & $0.064 *$ & 0.496 & $0.216^{* *}$ \\
\hline \multicolumn{7}{|l|}{ Control variables } \\
\hline Country of origin & Yes & & Yes & & & \\
\hline R-square & 0.10 & & 0.10 & & 0.03 & \\
\hline F-test (p-values) & 0.00 & & 0.00 & & 0.00 & \\
\hline Number of observations & 845 & & 845 & & 845 & \\
\hline Number of groups & & & & & 308 & \\
\hline
\end{tabular}

